\title{
ПРОФЕССОР ШУРА-БУРА БОРИС ЛУКИЧ: К 115-ЛЕТИЮ СО ДНЯ РОЖДЕНИЯ
}

\author{
Сметанин Виктор Николаевич \\ кандидат медицинских наук, дочент, \\ дочент кафедры эпидемиологии Рязанского государственного \\ медицинского университета имени академика И.П. Павлова, \\ 390026 г. Рязань, ул. Высоковольтная, д. 9 \\ Кирюшин Валерий Анатольевич \\ доктор медицинских наук, профессор, \\ заведующий кафедрой профильных гигиенических дисциплин с \\ курсом гигиены, эпидемиологии и организаџии госсанэпидслужбы ФДПО \\ Рязанского государственного медицинского университета \\ имени академика И.П. Павлова, \\ 390026 г. Рязань, ул. Высоковольтная, д. 9 \\ Здольник Татьяна Давыдовна \\ доктор медицинских наук, доцент, \\ заведующая кафедрой эпидемиологии Рязанского государственного \\ медицинского университета имени академика И.П. Павлова, \\ 390026 г. Рязань, ул. Высоковольтная, д. 9
}

Аннотация. Статья посвящена 115 -летию со дня рождения отечественного ученого-эпидемиолога, доктора медицинских наук, профессора, полковника медицинской службы Бориса Лукича Шура-Бура. Среди исследований Б.Л. Шуры-Буры особое место занимают работы по изучению переносчиков инфекции, роли синантропных мух в распространении заболеваний.

Annotation. The article is devoted to the 11th5thanniversary of the birth of the national scientist-epidemiologist, Doctor of Medical Sciences, Professor, Colonel of the Medical Service Boris Lukich Shura-Bur. Among the studies of B.L. Shura-Bura, a special place is occupied by work on the study of the pencarriers ofinfection, the role of synanthropic flies in the spread of diseases.

Ключевые слова: Юбилей, профессор Б.Л. Шура-Бура.

Key words: Jubilee, Professor B.L. Shura-Bura.

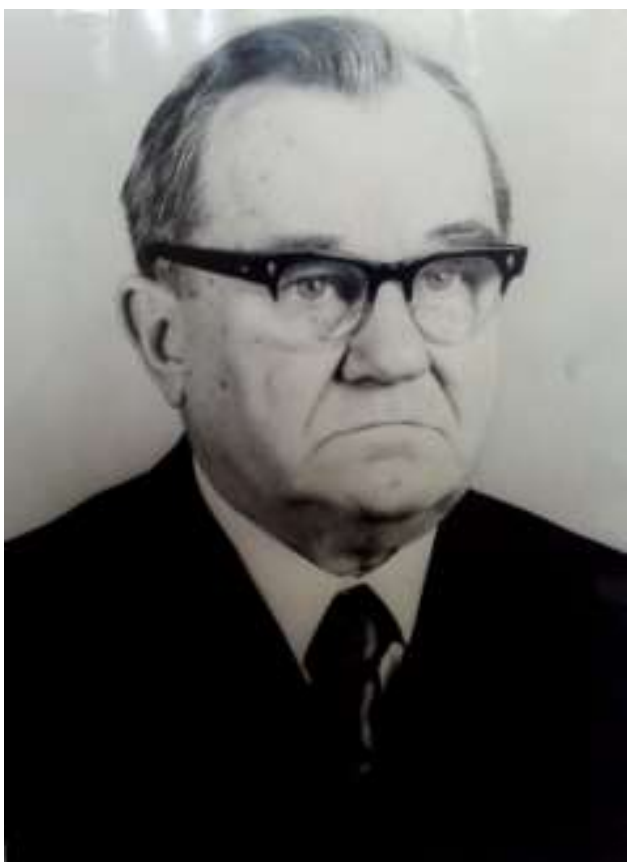

Борис Лукич Шура-Бура родился 6 ноября 1906 года в г. Москве в семье служащего железной дороги. В 1919 год вместе с семьей переехал в г. Киев, где закончил трудовую школу, затем фельдшерские курсы, а в 1931 г. - лечебно-профилактический факультет Киевского медицинского института. После института был на практической работе в г. Кзыл-Орда Казахской ССР, где руководил клиническим и (по совместительству) гигиеническим отделом Санитарно-бактериологической лаборатории. 
В 1932 году Борис Лукич отбывал цензовую военную службу в г. Кушке Узбекской ССР, после чего в 1933 г. переехал в г. Калугу и работал здесь в лаборатории железнодорожной больницы. Из Калуги перевелся в г. Ленинград на должность зав. лаборатории поликлиники № 26.

В 1937 году Б.Л. Шура-Бура был призван в ряды ВМФ и назначен начальником лаборатории госпиталя на о. Русском, а через год переведен во Владивосток в санитарно-эпидемиологическую лабораторию Тихоокеанского флота. В СЭЛ ТОФ на протяжении 8 лет последовательно выполняя функции бактериолога, эпидемиолога, начальника СЭЛ, приобрел опыт противоэпидемической работы, особенно в области борьбы с кишечными инфекциями и природно-очаговыми заболеваниями.

В период работы на флоте Борис Лукич написал кандидатскую диссертацию на тему «Опыт борьбы с вируорассеиванием дизентерийными хрониками» - о значении хронических больных в эпидемиологии дизентерии, использовав свои многолетние наблюдения и опыт борьбы с дизентерией на флоте, а также выполнил экспериментальную часть работы. Кандидатскую диссертацию Б.Л. Шура-Бура успешно защитил в 1946 году.

В 1945г. Борис Лукич вступил в ряды КПСС.

В период Великой Отечественной войны возглавил в качестве начальника СЭЛ Тихоокеанского флота работу по противоэпидемическому обеспечению кораблей и баз и принимал участие в подготовке эпидемиологов на курсах усовершенствования медицинского состава флота.

В 1945г. Б.Л. Шура-Бура был переведен в Военно-Морскую медицинскую академию в г. Ленинграде, где работал непрерывно до 1952 г. на различных преподавательских должностях. В 1947 г. по рекомендации, акад. Е. Н. Павловского начал экспериментальную разработку темы о роли синантропных мух в эпидемиологии дизентерии, учитывая, что и зарубежные и отечественные литературные данные по этой проблеме были очень разноречивы, а правильное решение ее представляло большой научный и практический интерес. Работа завершилась написанием диссертации на соискание ученой степени доктора медицинских наук по теме «Синатотропные мухи, как переносчики дизентерии», которая была защищена в 1952 году. 24 июня 1954 года Б.Л. Шура-Бура был утвержден в звании профессора по кафедре «военно-морская гигиена и эпидемиология».

Помимо работы над диссертацией Борис Лукич в 1947-1952 гг. принял участие в написании разделов учебника «Практическая эпидемиология» и монографии «Эпидемиологическая география», а также выполнил ряд научных исследований по плану НИР академии.

В 1953 г. Б.Л. Шура-Бура был назначен начальником кафедры военной эпидемиологии и гигиены с курсом специальной физиологии военно-морского факультета I Ленинградского медицинского института, где читал курс военной эпидемиологии. В период работы на факультете с 1953 по 1957 гг. занимался разработкой вопросов паразитологии и медицинской энтомологии, в первую очередь изучением биоэкологии переносчиков с применением сравнительно нового тогда метода радиоактивных изотопов. Исследования этого направления были продолжены в кандидатских диссертациях его учеников (Зайденов А.М. Харламов В.П.).

В 1957 г. после ликвидации факультета Борис Лукич был назначен заместителем начальника кафедры военной эпидемиологии с дезинфекцией Военно-медицинской академии им. С.М. Кирова. В 1957-1965гг. в Военно-медицинской академии читал полные курсы лекций по эпидемиологии и дезинфекции на факультетах подготовки сухопутных и морских врачей и факультетов усовершенствования (эпидемиологов, инфекционистов, гигиенистов, микробиологов и др.) Читал избранные лекции по военной эпидемиологии для преподавателей гражданских медицинских ВУЗов.

В 1967 года Борис Лукич закончил военную службу в звании полковника медицинской службы.

Б.Л. Шура-Бура принял участие в написании и редактировании учебников общей эпидемиологии (1962), частной военной эпидемиологии (1962), пособия к практическим занятиям (1961), сборника трудов (том 160) ВМОЛА на спецтему.

Б.Л. Шура-Бура был членом эпидемиологической секции Ученого медицинского совета при начальнике Центрального Военно-медицинского управления, Ленинградского отделения общества эпидемиологов, микробиологов и инфекционистов, Ленинградского общества паразитологов, Всесоюзного энтомологического общества; членом ученого совета Военно-медицинского музея; членом Технического совета Ленинградском областной санэпидстанции; членом Совета Ленинградской городской дезинфекционной станции.

9 февраля 1967 году Б.Л. Шура-Бура был избран на должность заведующего кафедрой эпидемиологии вновь созданного санитарно-гигиенического факультета Рязанского медицинского института имени академика И.П. Павлова, где проработал до 1974 года. С 1975 по 1976 гг. Борис Лукич был научным консультантом этой кафедры.

Б.Л. Шура-Бура имеет более 210 научных работ по различным вопросам эпидемиологии, значительная часть которых посвящена изучению возбудителей кишечных, стафилококковых инфекций, туляремии, глубоких микозов и эпидемиологии различных инфекционных заболеваний. Среди исследований Бориса Лукича особое место занимают работы по изучению переносчиков инфекций. Большое теоретическое и практическое значение имеют его исследования роли синантропных мух в распространении инфекции. Б.Л. Шура-Бура был изучен характер заражённости мух возбудителями кишечных инфекций, сроки их сохранения на мухах, а также степень 
заражённости мух на разных по санитарному благоустройству территориях страны. Ряд работ посвящён вопросам дезинфекции, дезинсекции и дератизации. В этой области им внесено 10 рационализаторских предложений. Все работы Б.Л.Шура-Бура отличались новизной постановки вопроса, применением новых методов исследования и имели большое теоретическое и практическое значение. Будучи военным медиком, полковник медицинской службы в отставке Б.Л. Шура-Бура уделял большое внимание разработке вопросов противоэпидемической защиты войск, дезинфекции в войсках и в системе гражданской обороны. Он являлся одним из авторов учебника по военной эпидемиологии и участвовал в создании Большой медицинской энциклопедии.

Большое внимание Б.Л. Шура-Бура уделял подготовке научных кадров. Под его руководством выполнены и защищены 9 кандидатских и 1 докторская диссертации.

Научно-педагогическую работу Борис Лукич успешно сочетал с большой общественной работой. Он был бессменным председателем Рязанского отделения ВНОМЭП. Б.Л. Шура-Бура был принципиальным, требовательным руководителем, отзывчивым товарищем, широко эрудированным человеком, щедро передававшим свои знания и опыт молодёжи.

Б.Л. Шура-Бура был женат и имел дочь Галину, 1938 г. рождения.

Б.Л. Шура-Бура награждён орденом Красной Звезды (1951), Красного Знамени (1956), медалями «За боевые заслуги» (1946), «Ветеран Вооружённых Сил СССР», «40 лет Вооружённых Сил СССР», «50 лет Вооружённых Сил СССР», «20 лет победы в Великой Отечественной войне 1941-1945 гг.».

Умер Б.Л. Шура-Бура 3 мая 1982 года и похоронен на Новогражданском кладбище г. Рязани, участок 15.

\section{Библиография}

1. Кирюшин В.А., Козеевская Н.А., Сметанин В.Н. Шура-Бура Борис Лукич: к 110-летию со дня рождения // Российский медико-биологический вестник имени академика И.П. Павлова. 2016. Т.24, № 4. С.173-176.

2. Книга памяти Рязанского государственного медицинского университета имени академика И.П. Павлова/сост.: Н.А. Козеевская; под ред. д.м.н., проф. Р.Е. Калинина, д.м.н., проф. В.А.Кирюшина; ФГБОУ ВО РязГМУ Минздрава России. - Рязань: РИО РязГМУ, 2015.-С.273-274.

3. Личный листок по учету кадров (1967) // Архив РМИ. Личное дело (1967-1974).

4. Никто не забыт. Ничто не забыто: сб. биографических материалов о со- трудниках РМИ/РязГМУ, участниках Великой Отечественной войны / редкол.: Д.Р. Ракита [и др.]; под общ. ред. Д.м.н., проф. Д.Р. Ракиты, д.м.н., проф. В.А. Кирюшина; ГОУ ВПО РязГМУ Росздрава.- Рязань: РИО РязГМУ, 2010.- С. 128.

5. Памяти Бориса Лукича Шура-Бура: [Некролог] // Мед. паразитология и паразитарные болезни. -1983.№1.-C.88-89.

6. Шура-Бура Борис Лукич: Автобиография (1967).

7. Шура-Бура Б.Л. // 60 лет на Рязанской земле (1950-2010): материалы по истории Рязанского гос. мед. ун-та им. акад. И.П. Павлова / авт. - сост.: Н.А. Козеевская; под ред. д.м.н., проф. Д.Р. Ракиты, д.м.н., проф. В.А. Кирюшина; РязГМУ им. акад. И.П. Павлова; науч. б-ка. - Рязань, 2010.- С.262-263. 